\title{
EVALUATION OF HEAVY METAL CONCENTRATION IN SOILS AND ROAD DUSTS OF SAGAMU AREA, SOUTHWESTERN NIGERIA
}

\author{
OMOTUNDE, V. B ${ }^{1^{*}}$ AND OLATUNJI, A. S ${ }^{2}$
}

${ }^{1}$ Pan African University Life and Earth Science Institute (including Health and Agriculture), University of Ibadan (*phickieomotunde@gmail.com)

${ }^{2}$ Department of Geology, University of Ibadan, Nigeria

(akinadeshadrach@yahoo.com)

This study was undertaken to assess the status and possible sources of heavy metals in the road dusts and soils of Sagamu, a town hosting one of the oldest Cement Work in Nigeria. In addition to the Cement work, the town has witnessed increased urbanization and industrialization necessitating the need to evaluate the quality status of some of the environmental media of the town.

Twenty road dusts and ten soil samples (at $20 \mathrm{~cm}$ depth) were collected from Sagamu area. The samples were disaggregated, sieved and analysed for elemental constituents by ICP-MS. The physico-chemical parameters of the samples were also determined. Geochemical results were subjected to statistical analysis and evaluation using contamination factor, Geo-accumulation indices, contamination degree, pollution load index and ecological risk assessment.

The concentration of the analysed heavy metals in the soils $(\mathrm{mg} / \mathrm{kg}$ ) showed that $\mathrm{Cu}$ ranged from 14-28, $\mathrm{Pb} 18-66$, $\mathrm{Zn}$ 25-462, while for the road dusts, $\mathrm{Cu}$ ranged from 8-106, $\mathrm{Pb} 18-240, \mathrm{Zn} 39-429$ and $\mathrm{Ni} 5-15$. The $\mathrm{pH}$ ranged from 6.66.9 and 6.6-7.2 for the soils and road dust respectively indicating slightly acidic to slightly alkaline media. The strong correlation observed among the metals and the grouping of the metals in one factor showed that the metals are from similar anthropogenic sources. The contamination factor within the sampled media showed the enrichment of $\mathrm{Cu}, \mathrm{Pb}$ and $\mathrm{Zn}$. The pollution load index and contamination degree were greater than 1 suggesting deterioration of the sampling sites. Geo-accumulation index revealed that the analysed metals have moderately contaminated the road dusts, while $\mathrm{Zn}$ and $\mathrm{Pb}$ have moderate contamination levels in the soils indicating a moderate environmental impact within the media. The ecological risk assessment showed that exposure to $\mathrm{Cu}, \mathrm{Pb}$ and $\mathrm{Zn}$ poses moderate to considerable risk to both the environment and human.

These metal enrichments were observed in area with high vehicular emissions, commercial centers, residential areas and in locations close to the cement factory. 